\title{
In vitro antibacterial activity of different adenosine analogues
}

\author{
Luca A. Vitali, ${ }^{1}$ Dezemona Petrelli, ${ }^{2}$ Catia Lambertucci, ${ }^{3}$ Manuela Prenna, ${ }^{2}$ \\ Rosaria Volpini ${ }^{3}$ and Gloria Cristalli ${ }^{3}$ \\ ${ }^{1}$ School of Pharmacy, Microbiology Unit, University of Camerino, via Gentile III da Varano, \\ 62032 Camerino (MC), Italy \\ ${ }^{2}$ School of Biosciences and Biotechnology, University of Camerino, via Gentile III da Varano, \\ 62032 Camerino (MC), Italy \\ ${ }^{3}$ School of Pharmacy, Medicinal Chemistry Unit, University of Camerino, via S. Agostino 1, \\ 62032 Camerino (MC), Italy
}

Correspondence

Luca A. Vitali

luca.vitali@unicam.it

Received 15 September 2011

Accepted 2 December 2011

\begin{abstract}
Nucleoside analogues may represent good candidates for the discovery of new antibacterial agents, therefore, a library of adenosine analogues was assessed for their antibacterial activity, and the relationship between the structure and activity of these molecules was outlined.

Antibacterial activity was evaluated against that of reference strains of Staphylococcus aureus, Staphylococcus epidermidis, Streptococcus pneumoniae, Escherichia coli and Pseudomonas aeruginosa. We tested 54 adenosine analogues, modified both at ribose and base moieties, including adenine and 1/3-deazaadenine derivatives substituted in the 2- and/or $N^{6}$-positions and bearing $N$-9 sugar moieties, such as ribose, 2'-deoxyribose, $3^{\prime}$-deoxyribose, $2^{\prime}, 3^{\prime}$-dideoxyribose or cycloalkyl groups like cyclopentane. The data obtained, MIC and minimal bactericidal concentrations demonstrated that the presence of bulky substituents such as cycloheptyl and cyclooctyl rings on the $N^{6}$-amino, together with a chlorine atom in the 2-position, conferred antibacterial activity against the Gram-positive group with MIC values ranging from 16 to $128 \mathrm{mg}$ $\mathrm{I}^{-1}$. The intact sugar moiety seemed to be not essential for antimicrobial activity and nucleosides bearing deoxyribose or cyclopentyl groups associated with bulky substituents in $N^{6}$-position showed good antimicrobial properties. Furthermore, $N-1$ proved to be non-crucial and the 2chloro- $N^{6}$-cyclooctyl-1-deaza-3'-deoxyadenosine and $2^{\prime}, 3^{\prime}$-dideoxyadenosine compounds were among the more active in the series with an MIC of $32 \mathrm{mg} \mathrm{I}^{-1}$ against Staph. aureus and Strep. pneumoniae. None of the analogues was active against the two Gram-negative species tested. Hence, adenosine derivatives bearing bulky substituents in the $N^{6}$-position may represent good lead compounds for the future discovery of a novel series of antibacterial agents.
\end{abstract}

\section{INTRODUCTION}

Antimicrobial resistance is growing at a fast rate and microorganisms such as methicillin-resistant Staphylococcus aureus (MRSA), staphylococci with decreased susceptibility to vancomycin, multi-drug resistant Gram-negative species and Streptococcus pneumoniae with decreased susceptibility to penicillin and other antibacterials are frequently isolated in both hospital and community settings (ECDC, 2010). Therefore, there is a growing need for novel antimicrobial agents with new mechanisms of action.

Nucleosides and their analogues are one class of compounds that are largely studied and used as antiviral and anti-tumour agents (Isono, 1988). Some derivatives show moderate to good activity against specific bacterial strains,

Abbreviation: MBC, minimal bactericidal concentrations. although, in the last two decades, studies on antibacterial properties have often been neglected in favour of those relating to antiviral and anti-tumour activity. Some recent experiences, however, have proven the great value of this field of research. For example, complex nucleosides exhibit antibacterial activity by specific inhibition of cell-wall peptidoglycan biosynthesis (Kimura \& Bugg, 2003), certain bacterial enzymes, such as purine nucleoside phosphorylases (Bzowska et al., 2000), and DNA ligases (Mills et al., 2011). In particular, adenosine analogues such as cordycepin (Ahn et al., 2000), 2'-amino-2'-deoxyadenosine and oxetanocin (Shimada et al., 1986), formycins (Bzowska et al., 2000), toyocamycin and its derivatives (Kimura \& Bugg, 2003) and some purine derivatives (Tunçbilek et al., 2009) showed biological activity including antibiotic properties. More detailed investigations on the antimicrobial activity of various classes of still untested nucleoside derivatives need 
to be conducted in order to maximize the potential for developing nucleoside analogues for the treatment of bacterial infections. In this study we present the antibacterial activity of a library of adenosine analogues.

\section{METHODS}

MICs and minimum bactericidal concentrations (MBCs) were determined by the broth microdilution method according to the Clinical and Laboratory Standards Institute guidelines (CLSI, 2009) and expressed in $\mathrm{mg} \mathrm{l}^{-1}$. The adenosine analogues tested are shown in Table
1. Their synthesis and chemical data were previously described (Cristalli et al., 1995; Salvatori et al., 2002; Vittori et al., 2000, 2006; Volpini et al., 1998, 1999), while compounds 53 and 54 will be described elsewhere. Stock solutions of the compounds were prepared in DMSO.

The panel of micro-organisms used in this study included Staph. aureus RN4200, Staph. epidermidis ATCC 35984, Strep. pneumoniae ATCC 49619, Escherichia coli ATCC 25922 and Pseudomonas aeruginosa ATCC 27853.

A test with DMSO alone was included as a negative control and one with the known antibiotic vancomycin against Staph. aureus was used as a positive control. Each experiment was repeated three times.

Table 1. Adenosine analogues used in this study

Cpd, compound; R, replacement/substituent group.

\begin{tabular}{|c|c|c|c|c|c|c|c|c|c|c|c|c|c|c|}
\hline Cpd & $\mathbf{R}$ & $\mathrm{R}_{1}$ & $\mathbf{R}_{2}$ & $\mathbf{R}_{3}$ & Cpd & $\mathbf{R}$ & $\mathrm{R}_{1}$ & $\mathbf{R}_{2}$ & $\mathbf{R}_{3}$ & Cpd & $\mathbf{R}$ & $\mathrm{R}_{1}$ & $\mathbf{R}_{2}$ & $\mathbf{R}_{3}$ \\
\hline 1 & $\mathrm{H}$ & $\mathrm{Cl}$ & $\mathrm{OH}$ & $\mathrm{OH}$ & 32 & $\mathrm{CH}_{3}$ & $\mathrm{Cl}$ & $\mathrm{OH}$ & $\mathrm{OH}$ & 50 & $\mathrm{H}$ & $\mathrm{Cl}$ & $\mathrm{OH}$ & $\mathrm{OH}$ \\
\hline 2 & $\mathrm{H}$ & I & $\mathrm{OH}$ & $\mathrm{OH}$ & 33 & $\mathrm{cC}_{3} \mathrm{H}_{5}$ & $\mathrm{Cl}$ & $\mathrm{OH}$ & $\mathrm{OH}$ & 51 & $\mathrm{H}$ & $\mathrm{Cl}$ & $\mathrm{H}$ & $\mathrm{OH}$ \\
\hline 3 & $\mathrm{H}$ & $\mathrm{SH}$ & $\mathrm{OH}$ & $\mathrm{OH}$ & 34 & $\mathrm{cC}_{4} \mathrm{H}_{7}$ & $\mathrm{Cl}$ & $\mathrm{OH}$ & $\mathrm{OH}$ & 52 & $\mathrm{cC}_{6} \mathrm{H}_{11}$ & $\mathrm{Cl}$ & $\mathrm{OH}$ & $\mathrm{H}$ \\
\hline 4 & $\mathrm{H}$ & $\mathrm{S}-\left(\mathrm{CH}_{2}\right)_{4} \mathrm{CH}_{3}$ & $\mathrm{OH}$ & $\mathrm{OH}$ & 35 & $\mathrm{cC}_{6} \mathrm{H}_{11}$ & $\mathrm{Cl}$ & $\mathrm{OH}$ & $\mathrm{OH}$ & & & & & \\
\hline 5 & $\mathrm{H}$ & $\mathrm{S}-\left(\mathrm{CH}_{2}\right)_{2}-\mathrm{Ph}$ & $\mathrm{OH}$ & $\mathrm{OH}$ & 36 & $\mathrm{cC}_{8} \mathrm{H}_{15}$ & $\mathrm{Cl}$ & $\mathrm{OH}$ & $\mathrm{OH}$ & & & & & \\
\hline 6 & $\mathrm{H}$ & S-cC ${ }_{5} \mathrm{H}_{9}$ & $\mathrm{OH}$ & $\mathrm{OH}$ & 37 & $\mathrm{H}$ & $\mathrm{Cl}$ & $\mathrm{H}$ & $\mathrm{OH}$ & & & & & \\
\hline 7 & $\mathrm{H}$ & $\mathrm{C} \equiv \mathrm{C}-\mathrm{nC}_{4} \mathrm{H}_{9}$ & $\mathrm{OH}$ & $\mathrm{OH}$ & 38 & $\mathrm{CH}_{3}$ & $\mathrm{Cl}$ & $\mathrm{H}$ & $\mathrm{OH}$ & & & & & \\
\hline 8 & $\mathrm{H}$ & $\mathrm{C} \equiv \mathrm{C}-\mathrm{Ph}$ & $\mathrm{OH}$ & $\mathrm{OH}$ & 39 & $\mathrm{cC}_{3} \mathrm{H}_{5}$ & $\mathrm{Cl}$ & $\mathrm{H}$ & $\mathrm{OH}$ & & & & & \\
\hline 9 & $\mathrm{H}$ & $\mathrm{C} \equiv \mathrm{C}-\mathrm{CH}(\mathrm{OH}) \mathrm{Ph}$ & $\mathrm{OH}$ & $\mathrm{OH}$ & 40 & $\mathrm{cC}_{6} \mathrm{H}_{11}$ & $\mathrm{Cl}$ & $\mathrm{H}$ & $\mathrm{OH}$ & & & & & \\
\hline 10 & $\mathrm{CH}_{3}$ & $\mathrm{C} \equiv \mathrm{C}-\mathrm{nC}_{4} \mathrm{H}_{9}$ & $\mathrm{OH}$ & $\mathrm{OH}$ & 41 & $\mathrm{cC}_{7} \mathrm{H}_{13}$ & $\mathrm{H}$ & $\mathrm{OH}$ & $\mathrm{H}$ & & & & & \\
\hline 11 & $\mathrm{CH}_{3}$ & $\mathrm{C} \equiv \mathrm{C}-\mathrm{Ph}$ & $\mathrm{OH}$ & $\mathrm{OH}$ & 42 & $\mathrm{cC}_{7} \mathrm{H}_{13}$ & $\mathrm{Cl}$ & $\mathrm{OH}$ & $\mathrm{H}$ & Cpd & $\mathbf{R}$ & & & \\
\hline 12 & $\mathrm{cC}_{3} \mathrm{H}_{5}$ & $\mathrm{Cl}$ & $\mathrm{OH}$ & $\mathrm{OH}$ & 43 & $\mathrm{cC}_{8} \mathrm{H}_{15}$ & $\mathrm{H}$ & $\mathrm{OH}$ & $\mathrm{H}$ & 53 & $\mathrm{H}$ & & & \\
\hline 13 & $\mathrm{cC}_{5} \mathrm{H}_{9}$ & $\mathrm{Cl}$ & $\mathrm{OH}$ & $\mathrm{OH}$ & 44 & $\mathrm{cC}_{8} \mathrm{H}_{15}$ & $\mathrm{Cl}$ & $\mathrm{OH}$ & $\mathrm{H}$ & 54 & $\mathrm{Cl}$ & & & \\
\hline 14 & $\mathrm{cC}_{7} \mathrm{H}_{13}$ & $\mathrm{H}$ & $\mathrm{OH}$ & $\mathrm{OH}$ & 45 & $\mathrm{H}$ & $\mathrm{Cl}$ & $\mathrm{H}$ & $\mathrm{H}$ & & & & & \\
\hline 15 & $\mathrm{cC}_{7} \mathrm{H}_{13}$ & $\mathrm{Cl}$ & $\mathrm{OH}$ & $\mathrm{OH}$ & 46 & $\mathrm{CH}_{3}$ & $\mathrm{Cl}$ & $\mathrm{H}$ & $\mathrm{H}$ & & & & & \\
\hline 16 & $\mathrm{CH}_{2} \mathrm{CH}(\mathrm{Ph})_{2}$ & $\mathrm{H}$ & $\mathrm{OH}$ & $\mathrm{OH}$ & 47 & $\mathrm{cC}_{6} \mathrm{H}_{11}$ & $\mathrm{Cl}$ & $\mathrm{H}$ & $\mathrm{H}$ & & & & & \\
\hline 17 & $\begin{array}{c}\mathrm{CH}_{2} \mathrm{CH}(\mathrm{Ph}) \mathrm{Ph}-(4- \\
\mathrm{OH})\end{array}$ & $\mathrm{Cl}$ & $\mathrm{OH}$ & $\mathrm{OH}$ & 48 & $\mathrm{cC}_{7} \mathrm{H}_{13}$ & $\mathrm{Cl}$ & $\mathrm{H}$ & $\mathrm{H}$ & & & & & \\
\hline 18 & $\mathrm{CH}_{2} \mathrm{CH}(\mathrm{Ph}) \mathrm{cC}_{6} \mathrm{H}_{11}$ & $\mathrm{H}$ & $\mathrm{OH}$ & $\mathrm{OH}$ & 49 & $\mathrm{cC}_{8} \mathrm{H}_{15}$ & $\mathrm{H}$ & $\mathrm{H}$ & $\mathrm{H}$ & & & & & \\
\hline 19 & $\mathrm{H}$ & $\mathrm{Cl}$ & $\mathrm{H}$ & $\mathrm{OH}$ & & & & & & & & & & \\
\hline 20 & $\mathrm{cC}_{5} \mathrm{H}_{9}$ & $\mathrm{Cl}$ & $\mathrm{H}$ & $\mathrm{OH}$ & & & & & & & & & & \\
\hline 21 & $\mathrm{cC}_{7} \mathrm{H}_{13}$ & $\mathrm{Cl}$ & $\mathrm{H}$ & $\mathrm{OH}$ & & & & & & & & & & \\
\hline 22 & $\mathrm{cC}_{8} \mathrm{H}_{15}$ & $\mathrm{H}$ & $\mathrm{H}$ & $\mathrm{OH}$ & & & & & & & & & & \\
\hline 23 & $\mathrm{cC}_{8} \mathrm{H}_{15}$ & $\mathrm{Cl}$ & $\mathrm{H}$ & $\mathrm{OH}$ & & & & & & & & & & \\
\hline 24 & $\mathrm{H}$ & $\mathrm{Cl}$ & $\mathrm{OH}$ & $\mathrm{H}$ & & & & & & & & & & \\
\hline 25 & $\mathrm{cC}_{5} \mathrm{H}_{9}$ & $\mathrm{H}$ & $\mathrm{OH}$ & $\mathrm{H}$ & & & & & & & & & & \\
\hline 26 & $\mathrm{cC}_{5} \mathrm{H}_{9}$ & $\mathrm{Cl}$ & $\mathrm{OH}$ & $\mathrm{H}$ & & & & & & & & & & \\
\hline 27 & $\mathrm{cC}_{5} \mathrm{H}_{8}-(2-\mathrm{OH})$ & $\mathrm{Cl}$ & $\mathrm{OH}$ & $\mathrm{H}$ & & & & & & & & & & \\
\hline 28 & 3-THF & $\mathrm{Cl}$ & $\mathrm{OH}$ & $\mathrm{H}$ & & & & & & & & & & \\
\hline 29 & $\mathrm{cC}_{3} \mathrm{H}_{5}$ & $\mathrm{H}$ & $\mathrm{H}$ & $\mathrm{H}$ & & & & & & & & & & \\
\hline 30 & $\mathrm{cC}_{5} \mathrm{H}_{9}$ & $\mathrm{Cl}$ & $\mathrm{H}$ & $\mathrm{H}$ & & & & & & & & & & \\
\hline 31 & $\mathrm{cC}_{7} \mathrm{H}_{13}$ & $\mathrm{Cl}$ & $\mathrm{H}$ & $\mathrm{H}$ & & & & & & & & & & \\
\hline
\end{tabular}


Table 2. MIC values $\left(\mathrm{mg} \mathrm{l}^{-1}\right)$ for adenosine analogues showing reliable antimicrobial activity

\begin{tabular}{|lrcc|}
\hline Compound & $\begin{array}{c}\text { Staph. } \\
\text { aureus }\end{array}$ & $\begin{array}{c}\text { Staph. } \\
\text { epidermidis }\end{array}$ & $\begin{array}{c}\text { Strep. } \\
\text { pneumoniae }\end{array}$ \\
\hline 4 & $>128$ & $>128$ & 128 \\
6 & $32-64$ & $>128$ & 128 \\
15 & $>128$ & $>128$ & 128 \\
16 & $>128$ & $>128$ & $>128$ \\
17 & 64 & 128 & 128 \\
18 & $>128$ & $>128$ & 128 \\
21 & $>128$ & $>128$ & 128 \\
23 & $>128$ & $>128$ & $>128$ \\
31 & $>128$ & $>128$ & 128 \\
35 & $>128$ & $>128$ & 128 \\
36 & 64 & 64 & $64-128$ \\
41 & $>128$ & $>128$ & 128 \\
42 & 64 & 128 & 64 \\
43 & $32-64$ & $>128$ & 128 \\
44 & 32 & 128 & 32 \\
47 & $>128$ & $>128$ & 128 \\
48 & 32 & $64-128$ & 32 \\
49 & $>128$ & $>128$ & 64 \\
53 & $>128$ & $>128$ & 16 \\
54 & $>128$ & $>128$ & 16 \\
& & & \\
\hline
\end{tabular}

Statistical analysis was performed on the antimicrobial activity MIC values by using the Kruskal-Wallis Test and multifactor analysis of variance in the STATGRAPHICS Centurion XV software package. The tested compounds were grouped and ranked based on the various substitutions at different sites. The $N^{6}$-substituted molecules were ranked according to size of the substituent and three main groups were identified: no substituent, substituents with $<5$ carbons, and substituents with $\geqslant 5$ carbons (bulky). The analogues substituted at the 2-position in the adenine moiety were grouped as halogenated, thioalkyl/cycloalkyl-, or alkynyl-substituted compounds. In addition, five groups were ranked based on variations in the sugar moiety: ribose, $2^{\prime}$-deoxyribose, $3^{\prime}$-deoxyribose, $2^{\prime}$ - 3 '-deoxyribose and analogues with the cyclopentyl group in place of the ribose.

\section{RESULTS AND DISCUSSION}

The data demonstrated that some of the compounds showed good antibacterial activity against all or some of the Gram-positives with MIC values ranging from 16 to $128 \mathrm{mg}^{-1}$ (Table 2). Among the adenosine derivatives 118, the presence of a 2-thioalkyl/cycloalkyl group (compounds 4 and 6) conferred antibacterial activity and, in particular, compound 6 proved to be one of the most active towards Staph. aureus (MIC 32-64 $\mathrm{mg} \mathrm{l}^{-1}$ ). The antibacterial activity of several 2-substituted adenosine analogues has recently been reported by Mills et al. (2011). This study showed that 2-thio-n-butyl adenosine was an inhibitor of the bacterial $\mathrm{NAD}^{+}$-dependent DNA ligase. In the present work, among the 2-substituted adenosine derivatives, the most active agents of the series were 2thio-n-pentyladenosine (compound 4) and 2-thio-cyclopentyladenosine (compound 6). The structure of these compounds is very similar to that of the previously reported $\mathrm{NAD}^{+}$-dependent DNA ligase inhibitors. Hence, it is possible to hypothesize that a similar mechanism of action is responsible for their antimicrobial activity.

On the other hand, the presence of halogens (compounds 1 and 2) or of a lipophilic alkynyl chain (compounds 7-11) in the same position led to inactive compounds. Moreover, compounds bearing bulky alkyl or aralkyl chains on the $N^{6}$ amino (compounds 15-18) showed antibacterial activity against Strep. pneumoniae $(P<0.05)$. The presence of a chlorine atom in the 2-position led to a derivative that was also active towards Staph. aureus (compound 17, MIC $64 \mathrm{mg} \mathrm{l}^{-1}$ ).

The intact sugar moiety seemed to be non-essential for activity against Strep. pneumoniae, and nucleosides bearing deoxyribose groups associated with bulky substituents in the $N^{6}$-position showed good antimicrobial properties. In particular, the $2^{\prime}$-deoxy derivative 21 and the $2^{\prime}, 3^{\prime}$-dideoxy derivative 31 , bearing a 2 -chlorine atom and an $N^{6}$ cycloheptyl ring, showed the highest activity in the series. On the other hand, the $3^{\prime}$-hydroxy group seemed to be more important for antimicrobial activity; in fact, none of the 3'-deoxy derivatives (compounds 24-28) displayed antimicrobial properties.

Furthermore, $\mathrm{N}-1$ proved to be non-crucial as the 2-chloro$N^{6}$-cyclooctyl-1-deaza-3' -deoxyadenosine and 2', $3^{\prime}$-dideoxyadenosine were among the most active compounds (compounds 44 and 48, MIC $32 \mathrm{mg} \mathrm{l}^{-1}$ against Staph. aureus and Strep. pneumoniae). On the contrary, none of the tested 3-deazaadenosine derivatives showed antibacterial activity, although general conclusions cannot be drawn for this subset of compounds given the limited number available for testing (compounds 50-52, Table 1).

When the ribose was replaced by a cyclopentyl group and an $N^{6}$-cyclooctyl substituent was introduced, compounds $53(\mathrm{R}=\mathrm{H})$ and $54(\mathrm{R}=\mathrm{Cl})$ were obtained (Table 1), which showed the highest antibacterial activity against Strep. pneumoniae (MIC $16 \mathrm{mg} \mathrm{l}^{-1}$, Table 2).

In conclusion, the presence of bulky substituents at $N^{6}$ position of the tested compounds led to molecules that showed, in general, good antimicrobial properties $(P<0.01)$. The simultaneous presence of a chlorine atom in the

Table 3. $\mathrm{MBC}$ values $\left(\mathrm{mg} \mathrm{l}^{-1}\right)$ for adenosine analogues showing the most reliable MIC values

$\mathrm{ND}$, Not determined (because of an MIC $\geqslant 64 \mathrm{mg} \mathrm{l}^{-1}$ ).

\begin{tabular}{|lcc|}
\hline Compound & Staph. aureus & Strep. pneumoniae \\
\hline 6 & $>128$ & ND \\
44 & $>128$ & 32 \\
48 & $>128$ & 32 \\
53 & ND & $>128$ \\
54 & ND & 16 \\
\hline
\end{tabular}


2-position conferred greater antibacterial activity in comparison with the unsubstituted compounds (e.g. compound 44, MIC $32 \mathrm{mg} \mathrm{l}^{-1}$ versus compound 43, MIC $128 \mathrm{mg} \mathrm{l}^{-1}$ against Strep. pneumoniae). The isosteric substitution of the nitrogen in the 1-position with a $\mathrm{CH}$ group resulted in nucleosides with improved antimicrobial activity against both Staph. aureus and Strep. pneumoniae (e.g. compound $31, \mathrm{MIC}=128 \mathrm{mg} \mathrm{l}^{-1}$, versus compound $48, \mathrm{MIC}=32 \mathrm{mg}$ $\left.1^{-1}\right)$. Table 3 shows the MBCs determined for compounds that had MICs $<64 \mathrm{mg} \mathrm{l}^{-1}$. Three of these compounds, 6, 44 , and 48, were bactericidal against Staph. aureus and three out of the five compounds with MICs $<64 \mathrm{mg} \mathrm{l}^{-1}$, namely 44, 48, and 54, when assayed with Strep. pneumoniae, had matching MBC and MIC values, indicating bactericidal activity. Interestingly, compound 53, which was inhibitory at a concentration of $16 \mathrm{mg} \mathrm{l}^{-1}$ as with compound 54, was not bactericidal against the Strep. pneumoniae. This finding suggests that the chlorine in the 2-position is sufficient to convert the analogue from bacteriostatic to bactericidal.

On the other hand, none of the analogues was active against the two Gram-negative species tested ( $P$. aeruginosa and E. coli), with the exception of the well-known derivative 19 (cladribine, 2-chloro-2'-deoxyadenosine), which had an MIC of $64 \mathrm{mg} \mathrm{l}^{-1}$ against the E. coli strain.

Adenosine and 1-deazaadenosine derivatives bearing bulky substituents in the $N^{6}$-position may represent good lead compounds for the future discovery of a novel series of antibacterial agents. A combination of substituents in the $N^{6}$-position with selected 2-thioalkyl/cycloalkyl chains could be a strategy to improve the antibacterial activity of this class of nucleosides.

Further studies to determine the mechanism of action of these compounds are necessary to identify their cellular target and to design and synthesize more potent analogues.

\section{ACKNOWLEDGEMENTS}

This work was supported by a grant from the Italian Ministry of Research: Ministero dell'Istruzione dell'Università e della Ricerca (MIUR) - PRIN (no. 2007LXNYS7_004) awarded to M.P.

\section{REFERENCES}

Ahn, Y. J., Park, S. J., Lee, S. G., Shin, S. C. \& Choi, D. H. (2000). Cordycepin: selective growth inhibitor derived from liquid culture of
Cordyceps militaris against Clostridium spp. J Agric Food Chem 48, 2744-2748.

Bzowska, A., Kulikowska, E. \& Shugar, D. (2000). Purine nucleoside phosphorylases: properties, functions, and clinical aspects. Pharmacol Ther 88, 349-425.

CLSI (2009). Performance standards for antimicrobial susceptibility testing, 19th informational supplement, M100-S19. Wayne, PA: Clinical and Laboratory Standards Institute.

Cristalli, G., Vittori, S., Eleuteri, A., Volpini, R., Camaioni, E., Lupidi, G., Mahmood, N., Bevilacqua, F. \& Palù, G. (1995). Synthesis and biological evaluation of $N^{6}$-cycloalkyl derivatives of 1-deazaadenine nucleosides: a new class of anti-human immunodeficiency virus agents. J Med Chem 38, 4019-4025.

ECDC (2010). Antimicrobial resistance surveillance in Europe 2009. In Annual Report of the European Antimicrobial Resistance Surveillance Network (EARS-Net). Stockholm: European Centre for Disease Prevention and Control. Available online: http://ecdc.europa.eu/en/ publications/Publications/1011_SUR_annual_EARS_Net_2009.pdf

Isono, K. (1988). Nucleoside antibiotics: structure, biological activity, and biosynthesis. J Antibiot (Tokyo) 41, 1711-1739.

Kimura, K. \& Bugg, T. D. H. (2003). Recent advances in antimicrobial nucleoside antibiotics targeting cell wall biosynthesis. Nat Prod Rep 20, 252-273.

Mills, S. D., Eakin, A. E., Buurman, E. T., Newman, J. V., Gao, N., Huynh, H., Johnson, K. D., Lahiri, S., Shapiro, A. B. \& other authors (2011). Novel bacterial $\mathrm{NAD}^{+}$-dependent DNA ligase inhibitors with broad-spectrum activity and antibacterial efficacy in vivo. Antimicrob Agents Chemother 55, 1088-1096.

Salvatori, D., Volpini, R., Vincenzetti, S., Vita, A., Costanzi, S., Lambertucci, C., Cristalli, G. \& Vittori, S. (2002). Adenine and deazaadenine nucleoside and deoxynucleoside analogues: inhibition of viral replication of sheep MVV (in vitro model for HIV) and bovine BHV-1. Bioorg Med Chem 10, 2973-2980.

Shimada, N., Hasegawa, S., Harada, T., Tomisawa, T., Fujii, A. \& Takita, T. (1986). Oxetanocin, a novel nucleoside from bacteria. J Antibiot (Tokyo) 39, 1623-1625.

Tunçbilek, M., Ateş-Alagöz, Z., Altanlar, N., Karayel, A. \& Özbey, S. (2009). Synthesis and antimicrobial evaluation of some new substituted purine derivatives. Bioorg Med Chem 17, 1693-1700.

Vittori, S., Lorenzen, A., Stannek, C., Costanzi, S., Volpini, R., IJzerman, A. P., Kunzel, J. K. V. F. D. \& Cristalli, G. (2000). N-cycloalkyl derivatives of adenosine and 1-deazaadenosine as agonists and partial agonists of the $A_{1}$ adenosine receptor. J Med Chem 43, 250-260.

Vittori, S., Dal Ben, D., Lambertucci, C., Marucci, G., Volpini, R. \& Cristalli, G. (2006). Antiviral properties of deazaadenine nucleoside derivatives. Curr Med Chem 13, 3529-3552.

Volpini, R., Camaioni, E., Costanzi, S., Vittori, S. \& Cristalli, G. (1998). Synthesis of new 3'-deoxyribonucleosides employing the acidcatalyzed fusion method. Helv Chim Acta 81, 2326-2331.

Volpini, R., Costanzi, S., Vittori, S., Cristalli, G. \& Lupidi, G. (1999). Synthesis and adenosine deaminase inhibitory activity of $3^{\prime}$-deoxy-1deazaadenosines. Helv Chim Acta 82, 2112-2118. 